\title{
Correct nomenclature for the Angadimogar pluton, Kerala, southwestern India
}

\author{
H M RAJESH \\ Graduate School of Life and Environmental Sciences, University of Tsukuba, Ibaraki 305-8572, Japan. \\ e-mail: rajesh.hm@gmail.com
}

The proper usage of modal composition and geochemical classification of granitoids is discussed for assigning a proper nomenclature for the Angadimogar pluton, Kerala, southwestern India. This discussion is mainly aimed at addressing questions concerning the nomenclature of Angadimogar pluton (syenite vs. granite). Modal composition and whole-rock XRD data clearly show that the pluton exposed near Angadimogar is a quartz-syenite and its geochemistry is typical of a ferroan, metaluminous, alkali (A-type) granitoid.

\section{Introduction}

Classification of granitoid rocks involving various criteria has long been a subject of frequent debate and voluminous literature. It can be a confusing exercise involving the minerals present and their relative proportion in the rock (depending largely on the chemical composition of the magma), the texture of the rock (depending largely on the cooling history of the magma), the colour of the rock (depending largely on the minerals present and on their grain size), and the chemical composition of the rock. Granitoid classification schemes have evolved from being genetic (e.g., Chappell and White 1974) and/or tectonic (e.g., Pearce et al 1984 ) in nature to non-genetic and non-tectonic in nature (e.g., Frost et al 2001). Controversies surrounding the classification of granitoid rocks are usually due to the usage of different schemes of classification by different workers. Such controversies rarely arise from the quality of geochemical data used. This study however, illustrates an example of misclassification of a granitoid rock due to the incorrect application of poor-quality geochemical data.

Anil Kumar et al (2005) reported geochemical data from two plutons (Angadimogar and Kumbdaje) from Kerala, southwestern India, and suggest that these bodies are granites based on their normative compositions. They apparently question the nomenclature of Angadimogar pluton (syenite vs. granite) used by Santosh and Nair (1986). Rajesh (1999) carried out a detailed field, petrographic, geochemical, and isotopic characterization of the Angadimogar pluton. The present paper is based on this work and intends to demonstrate that the pluton exposed near Angadimogar is a quartz-syenite.

\section{Study area and field relations}

The Neoproterozoic granulite-facies terrain of southwestern India is intruded by a suite of high-K calc-alkalic plutons (metaluminous to slightly peraluminous biotite granites and hornblende-biotite granites) with subsequent widespread alkaline (A-type) plutons (including quartz syenites) and minor garnet-bearing leucogranites (Rajesh 1999, 2000, 2003, 2004). These granitoids, emplaced between $\sim 640$ and $500 \mathrm{Ma}$ (figure 1a), were generated in environments of high heat flow and volatile activity, correlative with an extensional tectonic regime (Rajesh 1999, 2003, 2004). The pluton exposed near Angadimogar (figure 1a), northern Kerala, belongs to this suite,

Keywords. Nomenclature; modal composition; whole-rock XRD; geochemistry; quartz-syenite; A-type granitoid. 


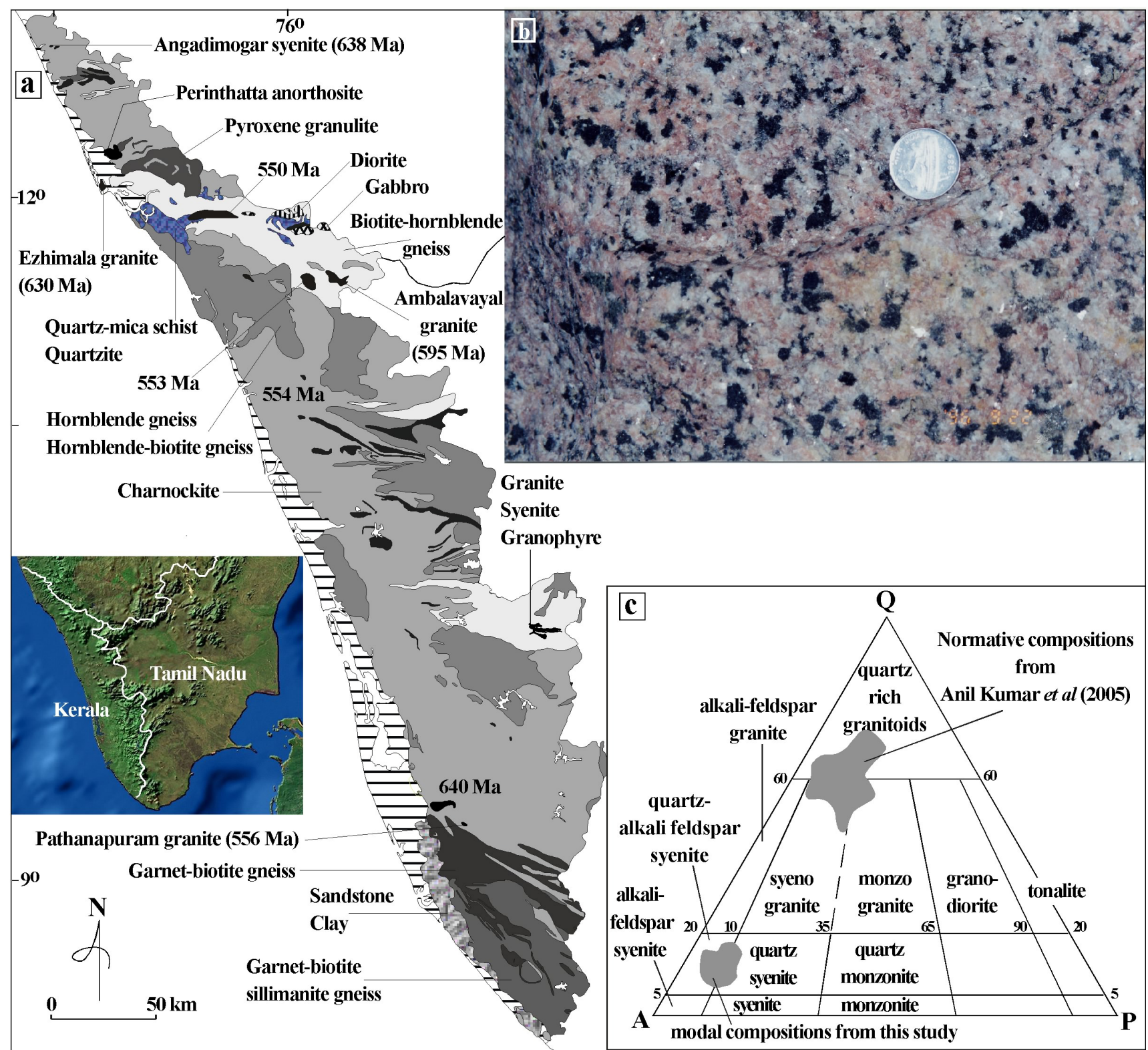

Figure 1. (a) Generalized geologic map of Kerala, southwestern India, showing the approximate location of granitoids and anorthositic gabbro mentioned in the text. Available ages of granitoids are also given. Inset is a shaded relief image of southern India showing the states of Kerala and Tamil Nadu. (b) Photograph illustrating the pink syenite exposed near Angadimogar, northern Kerala. (c) Modal composition (this study) and normative compositions (reproduced from Anil Kumar et al 2005) of the Angadimogar samples in a QAP plot. The three components, Q (quartz), A (alkali (Na-K) feldspar), and $\mathrm{P}$ (plagioclase), were recalculated from the modal amounts to sum to 100 per cent (as recommended by IUGS). The plagioclase ratio $(100 \times P /(A+P))$ is also useful to name the rock, as the non-horizontal divisions in the QAP diagram are lines of constant plagioclase ratio.

and is a quartz-syenite composed dominantly of medium- to coarse-grained K-feldspar, with minor amounts of quartz, plagioclase and uniformly distributed ferromagnesian minerals (figure 1b). Greenish amphibole constitutes the principal mafic constituent with minor biotite. This is in contrast to other syenites in southwestern India, where pyroxene constitutes the main mafic mineral. The syenitic body shows variations from a coarse-grained rock rich in pink feldspar, with large hornblende grains and minor quartz, to a medium- to coarse-grained rock rich in pink K-feldspar, with fine-grained hornblende, to a medium-grained rock rich in grey feldspar, with finer grained hornblende. The syenite is locally cut by thin $(<2 \mathrm{~cm})$ amphibolebearing veinlets. Pegmatites and aplites cut across the syenite exposures and attest to the presence of late-stage fluids.

The syenite shows an intrusive relationship with the surrounding light coloured, medium- to coarsegrained (sometimes migmatitic) hornblende-biotite 
gneiss/biotite-hornblende gneiss, often carrying boudins and bands (concordant as well as discordant) of amphibolites. These ortho-gneisses range in composition from alkali-feldspar-granite with less than $6 \%$ modal biotite to tonalite with up to $10 \%$ biotite. Hornblende-rich granitoid is much more common than biotite-rich granitoid. Dark greenish-grey coloured, medium grained, orthopyroxene-bearing quartzo-feldspathic charnockite is exposed in the northwestern and southeastern parts of the study area. This rock also contains hornblende and biotite, with occasional garnet.

\section{Petrography}

For plutonic rocks with less than 90\% (by volume) mafic (dark) minerals, the rock name is determined from the relative proportions of quartz, alkali feldspars, plagioclase feldspars, and felspathoids (nepheline, leucite, etc.). In any classification scheme, boundaries between classes are set arbitrarily; however, if the boundaries can be placed close to natural divisions or gaps between classes, they will seem less random and subjective, and such standards can facilitate universal understanding. The most commonly used scheme was devised by the International Union of Geological Sciences (IUGS) and is based on Streckeisen (1976) (figure 1c). IUGS recommends that if the mineral mode cannot be determined (or difficult to determine) as is often the case for volcanic rocks, then a chemical classification (e.g., total alkali versus silica diagram of Le Bas et al (1986)) is better. More discussions on this topic can be found in Le Bas and Streckeisen (1991) and Le Maitre et al (2002).

Modal analyses (obtained by point counting) of representative samples from the Angadimogar pluton plotted on a Streckeisen (1976) QAP plot indicates that they range in composition from quartz-syenite to quartz-alkali-feldsparsyenite (figure 1c). Whole rock XRD analyses were carried out as part of this study on powdered rock samples from six representative plutons (three granites, one anorthositic gabbro, and two syenites, including the Angadimogar pluton) across southwestern India, using a Philips PW3020 model X-ray diffractometer (housed at Fukuoka University of Education, Japan), using Ni-filtered, $\mathrm{CuK} \alpha$ radiation and a scanning speed of $1^{\circ} \mathrm{min}^{-1}$. All the representative whole-rock XRD plots of southwestern Indian granites (e.g., Ezhimala, Ambalavayal, Pathanapuram granites (see figure 1a)) show clear peaks for the main granitic minerals quartz and feldspar (figure 2). On the other hand, Angadimogar syenite whole-rock XRD pattern is similar to that of Puttetti syenite (Rajesh 2003) and Perinthatta anorthositic gabbro (see figure 1a;
Rajesh 2005), with a dominant peak for feldspar (figure 2). The syenite shows a general allotriomorphic texture and consists predominantly of perthitic orthoclase $(68-75 \%)$, normally zoned plagioclase (6-9\%), and a variety of mafic minerals: amphibole (potassian-ferro edenitic hornblende to ferro edenite to ferro actinolite (in the nomenclature of Giret et al 1980)), clinopyroxene (diopside (in the nomenclature of Morimoto 1988)), and biotite (annite) (Rajesh 1999). In some samples acmite was found. Quartz occurs as interstitial grains. Magnetite is the main opaque phase and is generally intergrown with ilmenite. Other accessory phases include zircon, allanite, apatite, titanite, calcite, and epidote.

\section{Geochemistry}

Santosh and Nair (1986), Rajesh (1999) and Anil Kumar et al (2005) presented geochemical data on the Angadimogar pluton. Representative major element data from these studies are given in table 1 . The syenite has high $\mathrm{K}_{2} \mathrm{O}$ (up to $6 \mathrm{wt} \%$ ). In terms of aluminium saturation index (ASI; Shand 1943) (which is better than A/CNK (molar $\left.\mathrm{Al}_{2} \mathrm{O}_{3} /\left(\mathrm{CaO}+\mathrm{Na}_{2} \mathrm{O}+\mathrm{K}_{2} \mathrm{O}\right)\right)$ in defining peralkaline/metaluminous/peraluminous compositions, as it takes into account the presence of apatite, and is expressed as the molecular ratio of $\mathrm{Al}, \mathrm{Ca}, \mathrm{P}, \mathrm{Na}$ and $\mathrm{K}$ ), Angadimogar syenite samples are clearly metaluminous (ASI $<1$ and molecular $\mathrm{Na}+\mathrm{K}<$ molecular $\mathrm{Al}$ ) similar to quartz-syenites worldwide and different from alkali-feldspar-syenites which are mostly peralkaline (e.g., Eby 1990; Nédélec et al 1995; Rajesh 2003). In such rocks (where ASI $<1$ and molecular $\mathrm{Na}+\mathrm{K}<$ molecular $\mathrm{Al}$ ) there is likely to be excess $\mathrm{Ca}$ after aluminium has been accommodated in the feldspars. As a result, metaluminous rocks contain calcic phases such as hornblende and augite but lack either muscovite or sodic ferromagnesian phases. This clearly accounts for the mineralogy of the Angadimogar syenite.

On the other hand, if ASI $>1$, then the rock is corundum-normative and peraluminous. This means that the rock has more $\mathrm{Al}$ than can be accommodated in feldspars and that it must have another aluminium phase present. For weakly peraluminous rocks this phase may be aluminous biotite, but for strongly peraluminous granites the phase can be muscovite, cordierite, garnet or an $\mathrm{Al}_{2} \mathrm{SiO}_{5}$ polymorph. All the 'granite' samples given in Anil Kumar et al (2005) are strongly peraluminous (ASI: 1.24-2.25 (Angadimogar); 1.78 (Kumbdaje); see table 1). But the mineralogy of both Angadimogar and Kumbdaje plutons mentioned in Anil Kumar et al (2005) (qtzkfs-plg-bt-pyx-hbl-opaques) includes no $\mathrm{Al}_{2} \mathrm{SiO}_{5}$ 


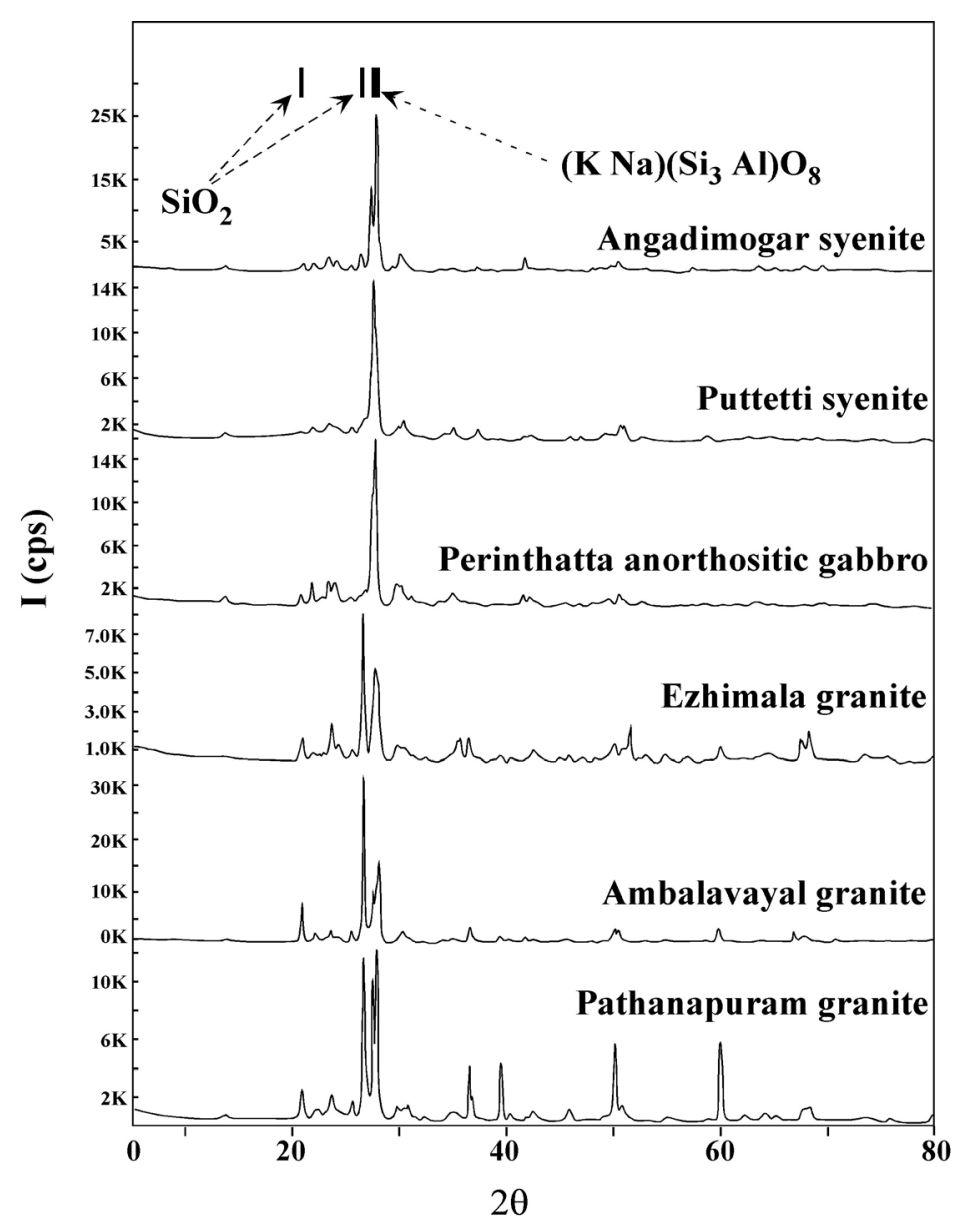

Figure 2. Representative whole-rock XRD plot of Angadimogar syenite compared with that of Ezhimala, Ambalavayal, and Pathanapuram granites, Puttetti syenite, and Perinthatta anorthositic gabbro, southwestern India. The granites show clear peaks for the main granitic minerals quartz and feldspar, while the syenites and anorthositic gabbro show a dominant peak for feldspar. Peaks of other identified minerals are not shown for clarity.

polymorph to characterize the strongly peraluminous nature. One reason for this can be the poor quality of geochemical data used.

Let me address the quality of geochemical data given in Anil Kumar et al (2005). At a glance the first thing that strikes a granitoid geochemist, is the extremely low $\mathrm{Na}_{2} \mathrm{O}$ content (0.23-0.65) of all the rock types from the study area (7 granite samples from Angadimogar pluton, 1 aplite sample, 3 gneiss samples and 1 charnockite sample from Angadimogar area, and 1 granite sample from Kumbdaje pluton; see table 1) (figure 3). The $\mathrm{Na}_{2} \mathrm{O}$ content of these samples were compared with $\mathrm{Na}_{2} \mathrm{O}$ contents of granites and syenites from southwestern India (Rajesh 1999, 2000, 2003, 2004), typical A-type granitoids (including quartzsyenites) given in Eby (1990), quartz-syenites from East Greenland, syenites (quartz-syenite to alkalifeldspar-syenite) from Russia, quartz-syenites from Antarctica, and quartz-syenites from Madagascar (see Rajesh 1999, for the references and compilation), typical peraluminous granites (Strong and Hamner 1981; Nabelek et al 1992; Inger and Harris 1993; Searle et al 1997), charnockite massifs from southern India (Rajesh and Santosh 2004 and references therein), hbl-bt gneiss/bt-hbl gneiss from central and northern Kerala (Nambiar et al 1992; Rajesh 1999), sodic and potassic garnetbiotite gneiss, garnet-biotite-sillimanite gneiss, and cordierite gneiss from southern Kerala (Chacko et al 1992), and mafic dykes from southern India (Radhakrishna et al 1995) (figure 3). It should be noted that quartz syenites with hornblende as the major mafic mineral (syenites from East Greenland, Russia and Antarctica) have similar $\mathrm{Na}_{2} \mathrm{O}$ contents with the Angadimogar syenite samples, while quartz syenites with pyroxene as the major mafic mineral (other syenites from southwestern India and Madagascar) have lower $\mathrm{Na}_{2} \mathrm{O}$ contents. A common feature of all these quartz-syenite studies is their modal per cent of quartz (average 10\%; sometimes reaching up to $\sim 19 \%$ ). This is comparable to modal contents used in this study as well as Santosh and Nair (1986). 

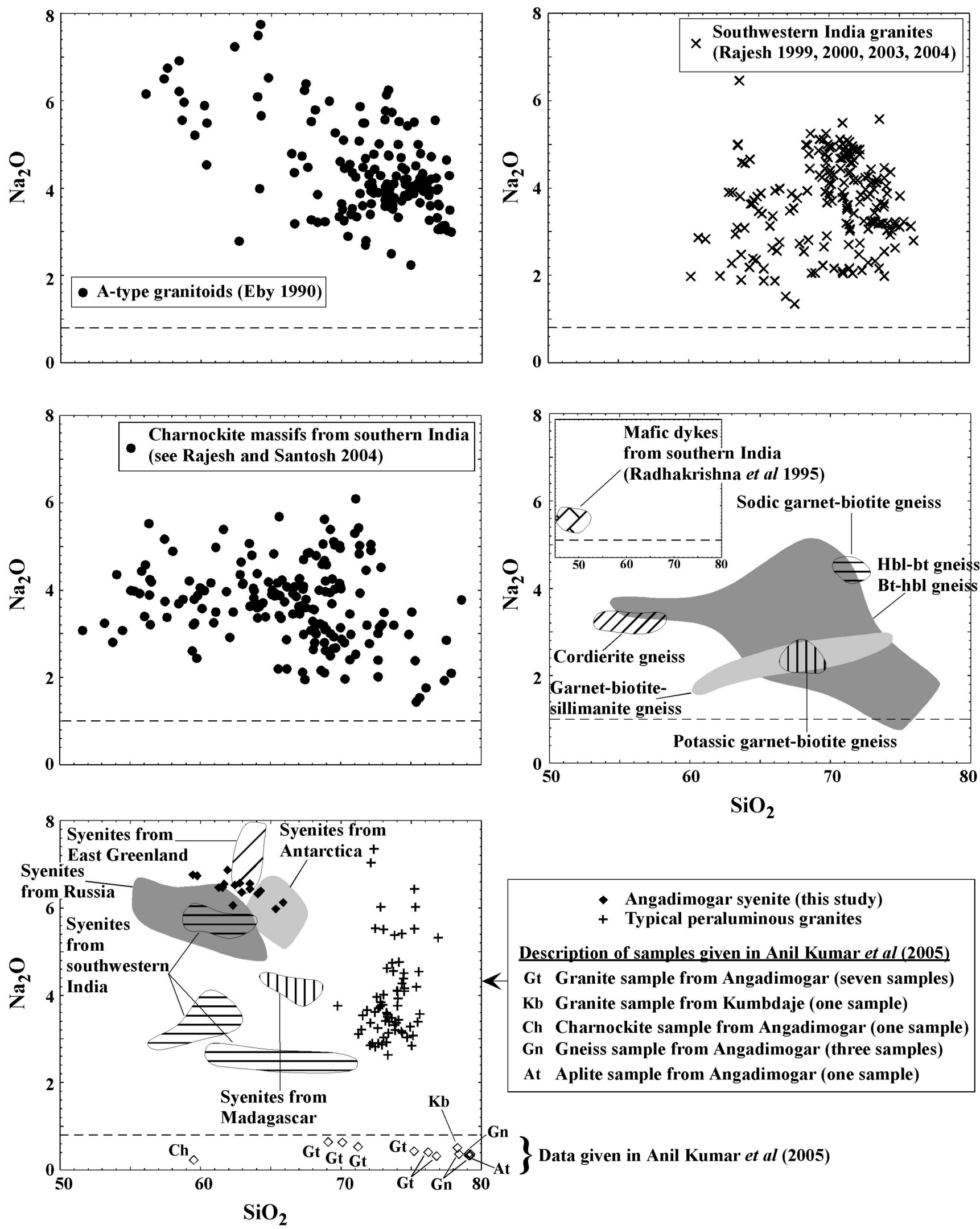

Figure 3. $\mathrm{Na}_{2} \mathrm{O}$ vs. $\mathrm{SiO}_{2}$ plots illustrating the compositional variance of the data presented in Anil Kumar et al (2005) in comparison with representative data from a range of rock types from southern India and elsewhere. The dotted line in each figure represents the upper limit of the data given in Anil Kumar et al (2005). None of the rock types have the extremely lower $\mathrm{Na}_{2} \mathrm{O}$ content as the samples given in Anil Kumar et al (2005). 


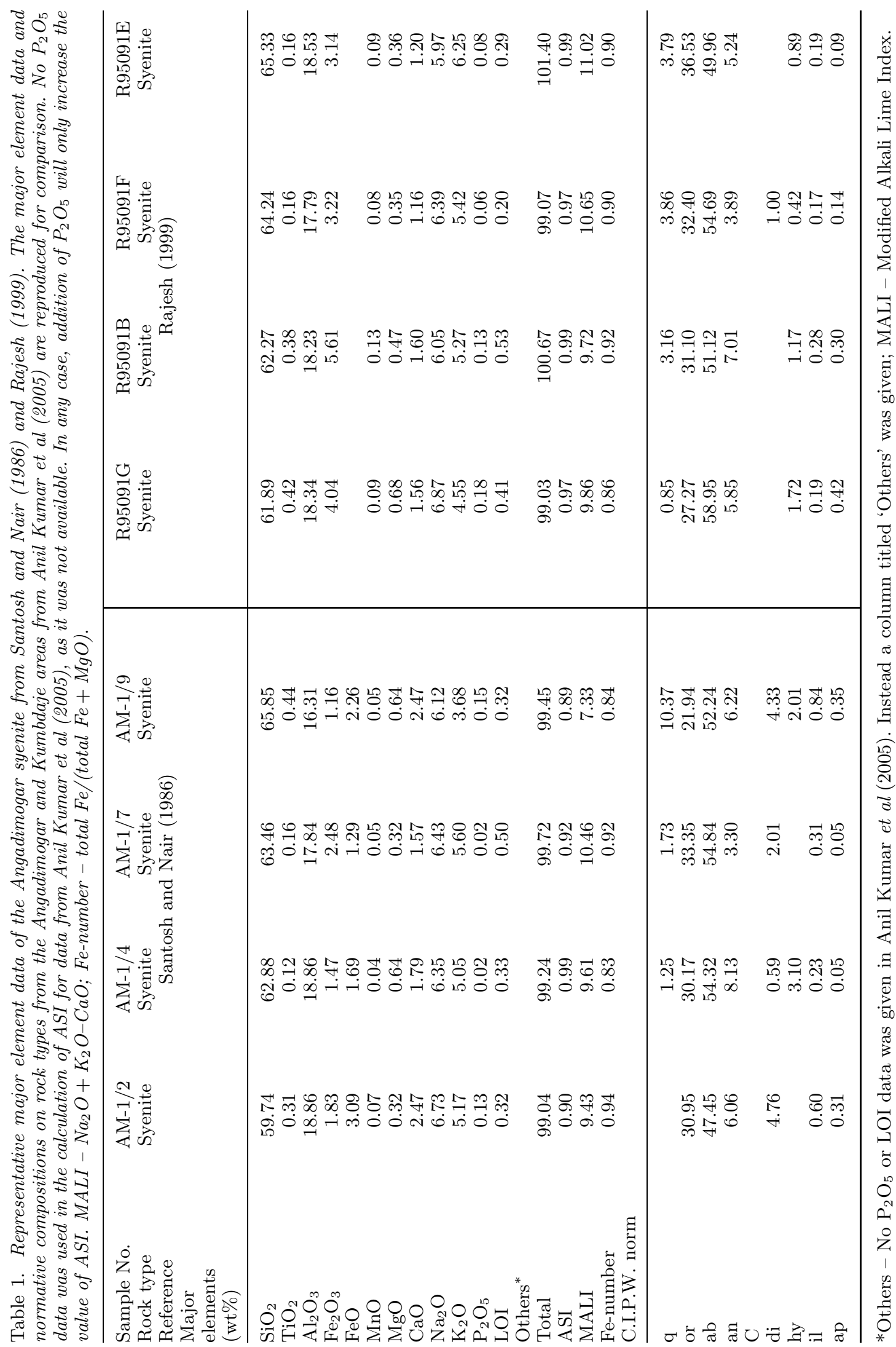


Correct nomenclature for Angadimogar pluton

\begin{tabular}{|c|c|c|c|c|c|}
\hline $\overrightarrow{\mathrm{T}}$ & 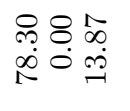 & 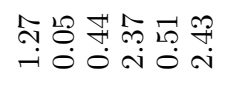 & 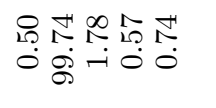 & 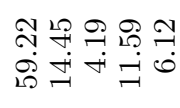 & $\overrightarrow{0}$ \\
\hline 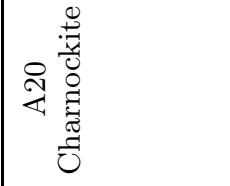 & 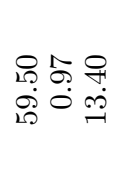 & 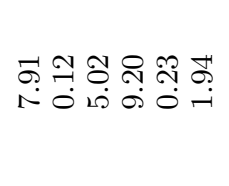 & 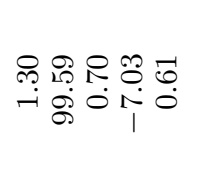 & 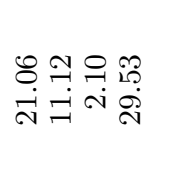 & 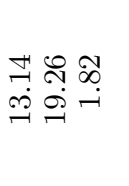 \\
\hline 乞皆 & 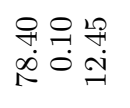 & 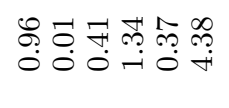 & 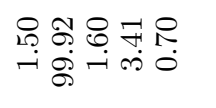 & 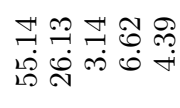 & 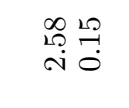 \\
\hline 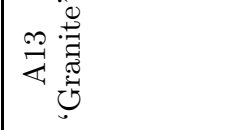 & 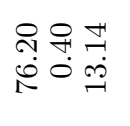 & 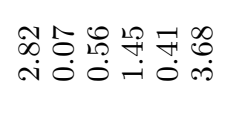 & 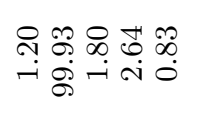 & 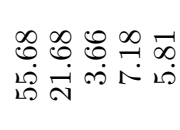 & 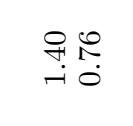 \\
\hline 总 & 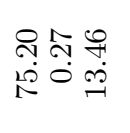 & 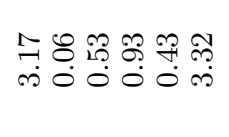 & 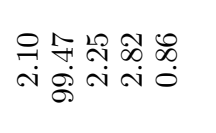 & 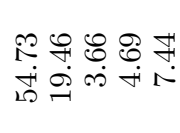 & $\begin{array}{l}\overrightarrow{1} \\
\infty \\
0 \\
0\end{array}$ \\
\hline 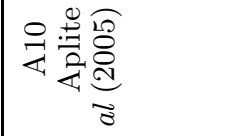 & 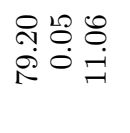 & 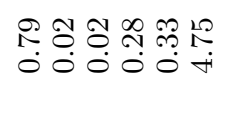 & 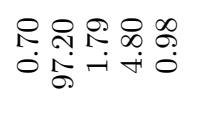 & 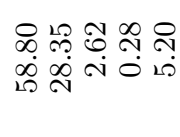 & $\stackrel{9}{\stackrel{2}{1} \stackrel{2}{0}}$ \\
\hline 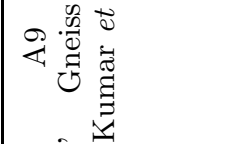 & 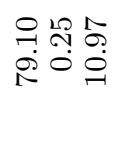 & 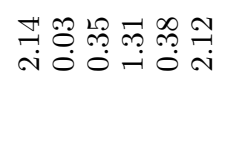 & 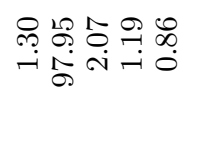 & 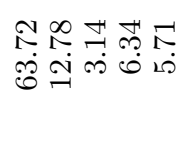 & 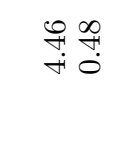 \\
\hline 足: & 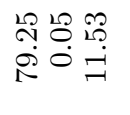 & 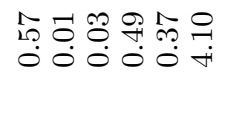 & 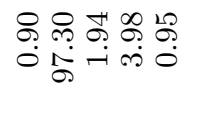 & 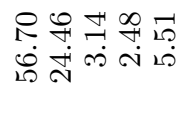 & 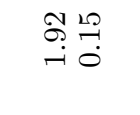 \\
\hline 公量 & 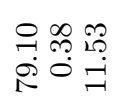 & 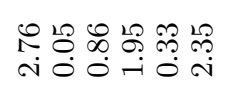 & 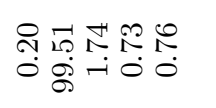 & 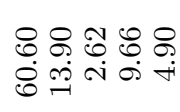 & $\begin{array}{l}250 \\
80 \\
00\end{array}$ \\
\hline 艺晜 & 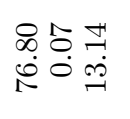 & 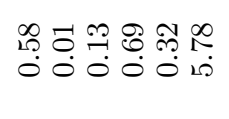 & 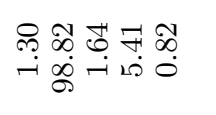 & 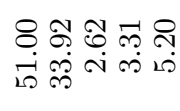 & $\stackrel{\text { กิ }}{\rightarrow} \stackrel{2}{-1}$ \\
\hline 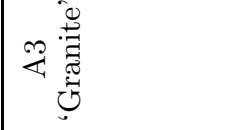 & 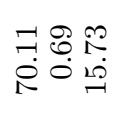 & 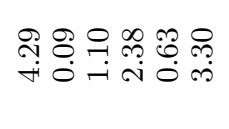 & 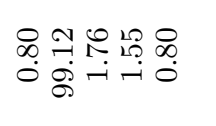 & 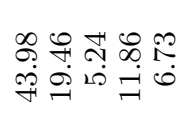 & 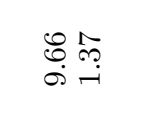 \\
\hline 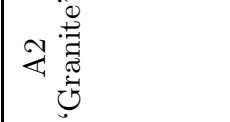 & 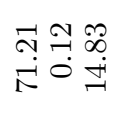 & 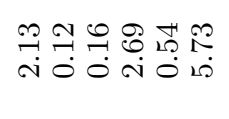 & 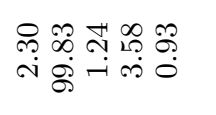 & 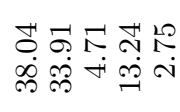 & 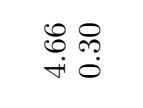 \\
\hline 《莺 & 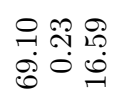 & 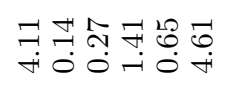 & 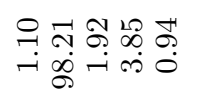 & 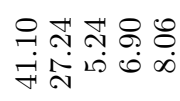 & 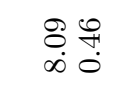 \\
\hline 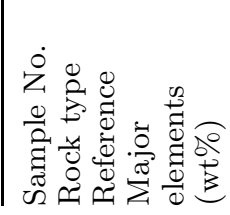 & 㱐 & 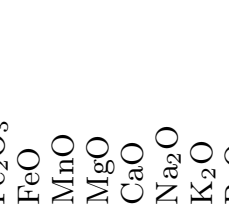 & $\begin{array}{l} \\
\end{array}$ & రి శి శี & $=$ \\
\hline
\end{tabular}




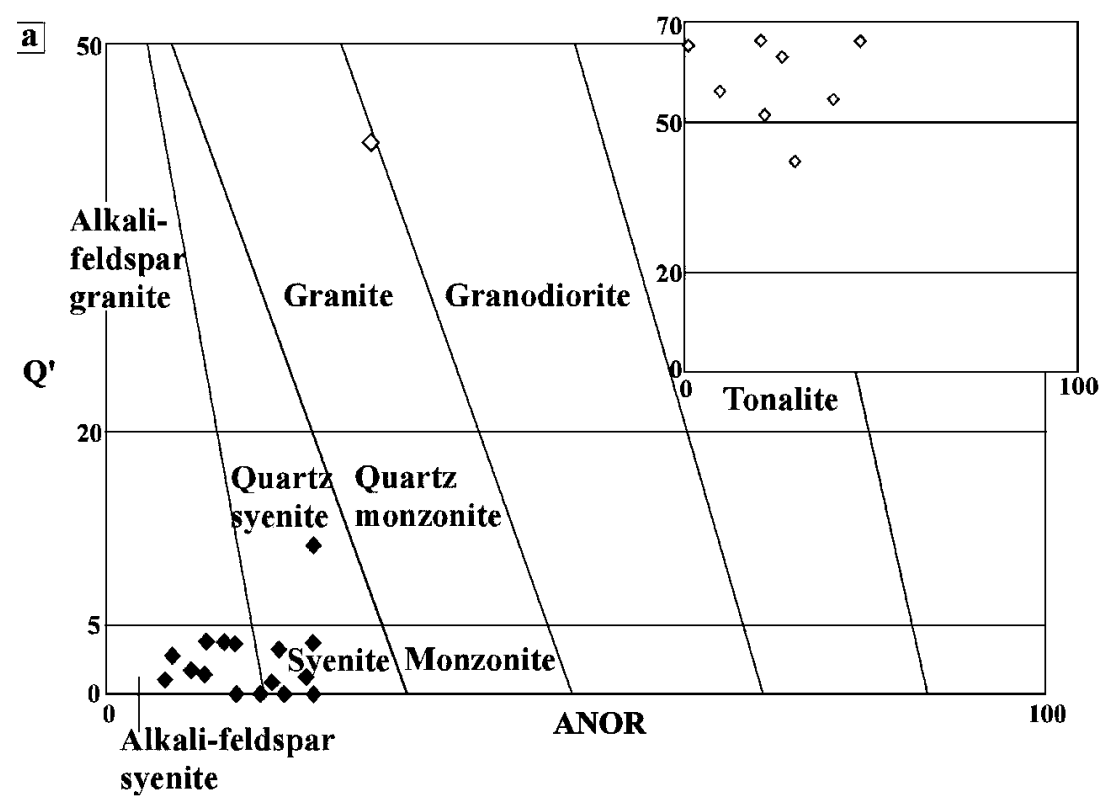

b

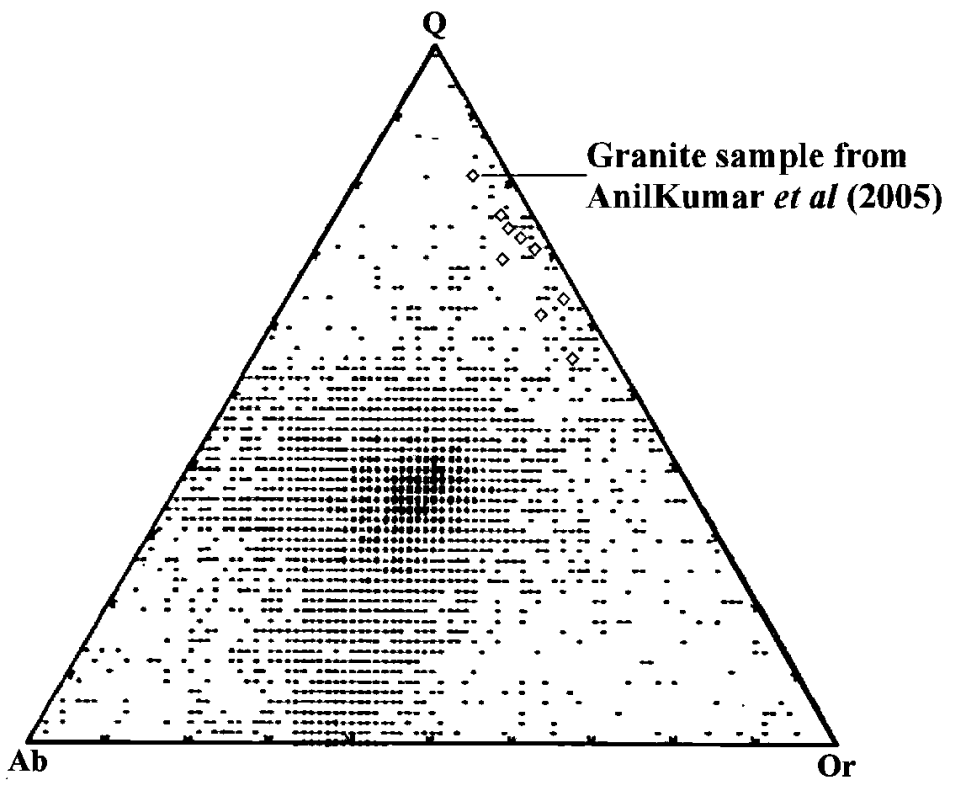

Figure 4. (a) Q' vs. ANOR plot for the Angadimogar syenite samples (filled symbols; this study), and 'granite' samples from Anil Kumar et al (2005) (open symbols). Inset shows the outlier samples from Anil Kumar et al (2005). (b) Normative compositions of granite samples given in Anil Kumar et al (2005) compared with similar compositions of 7659 granitic rocks from around the world. Note that about $50 \%$ of the analyses fall within only about $5 \%$ of the diagram (analyses compiled and plotted courtesy of Roger W Le Maitre, Tasmania).

None of the rock types given in figure 3 have such extremely lower $\mathrm{Na}_{2} \mathrm{O}$ content as the samples given in Anil Kumar et al (2005). Even typical peraluminous granites do not have such low $\mathrm{Na}_{2} \mathrm{O}$. In the absence of data on analytical accuracy and precision in the Anil Kumar et al (2005) paper, the only way I can explain the extremely low and similar $\mathrm{Na}_{2} \mathrm{O}$ content of granite, gneiss, charnockite, and aplite samples analysed by them is poor data quality. This low $\mathrm{Na}_{2} \mathrm{O}$ combined with the high $\mathrm{Al}_{2} \mathrm{O}_{3}$ content translates to a corundum normative composition and hence a peraluminous rock, but without an $\mathrm{Al}_{2} \mathrm{SiO}_{5}$ polymorph to account for the peraluminous composition.

\section{Normative compositions and the nomenclature of Angadimogar pluton}

Anil Kumar et al (2005) calculate normative compositions from their geochemical data and plot it in the QAP diagram of Streckeisen (1976) (see figure 1c). It is quite clear from figure 1(c) that plotting normative compositions and modal 
compositions of the same pluton in the QAP plot can lead to a significant difference in nomenclature. Streckeisen and Le Maitre (1979) put forward the Q' - ANOR method, which is approximately equal to that of the modal QAP diagram of IUGS, for usage with normative compositions. In the Q' ANOR plot (figure 4a) samples from this study plot in the syenite field, while most of the 'granite' samples from Anil Kumar et al (2005) plot out of the fields covered by the diagram (see inset in figure 4a). This uncertainty of the normative compositions of the 'granite' samples is further visible in figure 4(b), where they are compared with normative compositions of 7659 granitic rocks from around the world (compiled and plotted by Le Maitre).

\section{Proper classification of the Angadimogar pluton}

Granitoid classification is problematic as the same mineral assemblage (quartz-feldsparferromagnesian minerals) can be achieved by a number of processes. A major drawback of the IUGS classification scheme is that it ignores compositional variations apart from those that affect the feldspar abundances. Because of this complexity, petrologists have relied upon geochemical classifications to distinguish between various types of granitoids. This study utilizes the geochemical classification of Frost et al (2001) based on Fe-number, modified alkali lime index, and ASI. Accordingly Angadimogar syenite is ferroan, alkalic, and metaluminous, typical of alkali (A-type) granitoids (figure 5). Data from Anil Kumar et al (2005) subjected to similar geochemical discrimination suggests that the Angadimogar pluton is magnesian to ferroan, calcic, and peraluminous (Kumbdaje is magnesian, calcic, and peraluminous) (figure 5). Interestingly, Frost et al (2001) points out that magnesian, calcic, and peraluminous compositions are shown by diorites, quartz diorites, and tonalites, while there is no known granitoid rock with ferroan, calcic, and peraluminous compositions.

\section{Concluding remarks}

Experimental results indicate that the partial melts generated deep in the crust are closer to syenite than granite in composition (e.g., Huang and Wyllie 1975). Low initial ${ }^{87} \mathrm{Sr} /{ }^{86} \mathrm{Sr}$ isotope ratio (0.7032 \pm 0.0008 ; Santosh and Nair 1986; Rajesh 1999) and estimated (using Al-in-Hbl geobarometry; Rajesh 1999) pressure conditions of $\sim 8 \mathrm{kbar}$ for the Angadimogar syenite translates to a deep crustal depth. The Angadimogar quartz-syenite
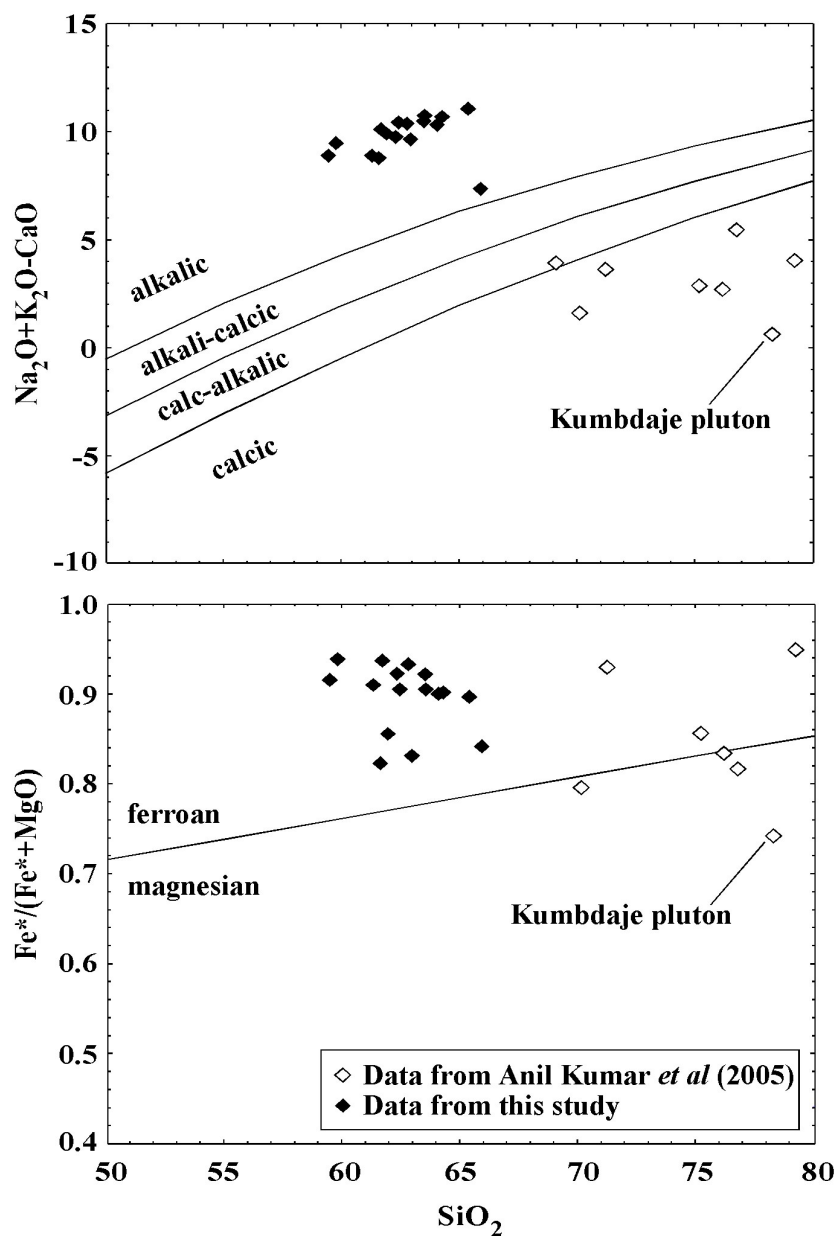

Figure 5. $\mathrm{Fe}^{*} /\left(\mathrm{Fe}^{*}+\mathrm{MgO}\right)$ vs. $\mathrm{SiO}_{2}$ and $\mathrm{Na}_{2} \mathrm{O}+\mathrm{K}_{2} \mathrm{O}-\mathrm{CaO}$ vs. $\mathrm{SiO}_{2}$ plots for the Angadimogar syenite samples, and 'granite' samples from Anil Kumar et al (2005).

belongs to the $\sim 640-500 \mathrm{Ma}$ granitoid magmatic activity along southwestern India (Rajesh 1999, $2000,2003,2004)$. It has all the geochemical characteristics of alkali (A-type) granitoids. Similar quartz-syenites have been reported from different continental fragments (Arabian shield (Harris 1985), Madagascar (Nédélec et al 1995), East Antarctica (Zhao et al 1995)), placed adjacent to India in a supercontinent framework.

The absence of any mineral (muscovite, cordierite, corundum, andalusite, tourmaline, topaz, garnet, cordierite, sillimanite) characteristic of peraluminous rock does not correlate with the peraluminous compositions presented for samples from the Angadimogar pluton (as well as Kumbdaje pluton) by Anil Kumar et al (2005). The mafic mineralogy (hornblende, clinopyroxene, biotite) of Angadimogar syenite is clearly characteristic of a metaluminous rock. Thus the syenite-granite nomenclature issue raised by Anil Kumar et al (2005) for the Angadimogar pluton (as well as Kumbdaje pluton) is just an artifact of using questionable geochemical data, and the improper usage of normative compositions in the QAP diagram. 


\section{Acknowledgements}

This work is dedicated to the fond memory of Sujith D Prasad, Geologist at Geoservices, who was more than an inspiration to all the 1994-Nattakombatch-mates. Sandeep Singh and Manoj Pandit provided perceptive and constructive comments on the manuscript. The reviewers are also thanked for taking the labour of going through the article of Anil Kumar et al (2005). Editorial comments by Hetu Sheth were valuable. Naomi Tashiro and Teiichi Ueno from the Fukuoka University of Education, Japan, helped with whole-rock XRD analysis. This is a contribution to the Gondwana Institute for Geology and Environment (GIGE) and IGCP 453.

\section{References}

Anil Kumar A, Gopinathan V, Gopinath K S and Rao V P 2005 A review on the nomenclature of Angadimogar and Kumbdaje plutons, Kasargod district, Kerala; J. Geol. Soc. India 65 141-146.

Chacko T, Kumar G R R, Meen J K and Rogers J J W 1992 Geochemistry of high grade supracrustal rocks from the Kerala Khondalite Belt and adjacent massif charnockites; Precamb. Res. 55 469-489.

Chappell B W and White A J R 1974 Two contrasting granite types; Pacific Geol. 8 173-174.

Eby G N 1990 The A-type granitoids: a review of their occurrence and chemical characteristics and speculations on their petrogenesis; Lithos 26 115-134.

Frost B R, Barnes C G, Collins W J, Arculus R J, Ellis D J and Frost C D 2001 A geochemical classification for granitic rocks; J. Petrol. 42 2033-2048.

Giret A, Bonin B and Leger J M 1980 Amphibole compositional trends in over saturated and under saturated alkaline plutonic ring-complexes; Can. Mineral. 18 481-495.

Harris N B W 1985 Alkaline complexes from the Arabian Shield; J. Afr. Earth Sci. 3 83-88.

Huang W and Wyllie P J 1975 Melting reactions in the system $\mathrm{NaAlSi}_{3} \mathrm{O}_{8}-\mathrm{KAlSi}_{3} \mathrm{O}_{8}-\mathrm{SiO}_{2}$ to $35 \mathrm{kbars}$, dry and with excess water; J. Geol. 83 737-748.

Inger S and Harris N 1993 Geochemical constraints on leucogranite magmatism in the Langthan Valley, Nepal Himalayas; J. Petrol. 34 345-368.

Le Bas M J and Streckeisen A L 1991 The IUGS systematics of igneous rocks; J. Geol. Soc. London 148 825-833.

Le Bas M J, Le Maitre R W, Streckeisen A and Zanettin B 1986 A chemical classification of volcanic rocks based on the total alkali-silica diagram; J. Petrol. 27 745-750.

Le Maitre R W, Streckeisen A, Zanettin B, Le Bas M J, Bonin B, Bateman P, Bellieni G, Dudek A, Efremova S, Keller J, Lameyre J, Sabine P A, Schmid R, Sørensen H and Woolley A R 2002 Igneous rocks: A classification and Glossary of Terms; 2nd edn, Cambridge Univ. Press, $252 \mathrm{p}$.

Morimoto N 1988 Nomenclature of pyroxenes; Mineral. Mag. 52 535-550.

Nabelek P I, Russ-Nabelek C and Denison J R 1992 Harney Peak leucogranite, Black Hills, South Dakota, USA: petrologic and geochemical constraints; Contrib. Mineral. Petrol. 110 173-191.

Nambiar C G, Bhaskar Rao B, Parthasarathy R and Fedkin V V 1992 Geochemistry and genesis of charnockites and associated gneisses from northern Kerala, India; In: In high-grade metamorphics (ed.) A Barto (Athens: Theophrastus Publishers) pp. 187-215.

Nédélec A, Stephens W E and Fallick A E 1995 The PanAfrican stratoid granites of Madagascar: alkaline magmatism in a post-collisional extensional setting; J. Petrol. 36 1367-1391.

Pearce J A, Harris N B W and Tuttle A C 1984 Trace element discrimination diagrams for the tectonic interpretation of igneous rocks; J. Petrol. 25 956-983.

Radhakrishna T, Pearson D G and Mathai J 1995 Evolution of Archaean southern Indian lithospheric mantle: a geochemical study of Proterozoic Agali-Coimbatore dykes; Contrib. Mineral. Petrol. 121 351-363.

Rajesh H M 1999 Characterization and origin of alkaline and calc-alkaline aluminous A-type granitoids from southwestern India: implications for Gondwanaland tectonics; Unpublished DSc thesis Osaka City University, Japan, $317 \mathrm{p}$.

Rajesh H M 2000 Characterization and origin of a compositionally zoned aluminous A-type granite from South India; Geol. Mag. 137 291-318.

Rajesh H M 2003 Outcrop-scale silicate liquid immiscibility from an alkali syenite (A-type granitoid)-pyroxenite association near Puttetti, Trivandrum Block, South India; Contrib. Mineral. Petrol. 145 612-627.

Rajesh H M 2004 The igneous charnockite - high-K alkalicalcic I-type granite - incipient charnockite association in Trivandrum Block, southern India; Contrib. Mineral. Petrol. 147 346-362.

Rajesh H M 2005 Progressive or continual exsolution in pyroxenes: an inidcator of polybaric igneous crystallization for the Perinthatta anorthositic gabbro, northern Kerala, southwestern India; J. Asian Earth Sci. (doi:10.1016/j.jseaes.2004.11.004).

Rajesh H M and Santosh M 2004 Charnockitic magmatism in southern India; J. Earth Sys. Sci. 113 $565-585$.

Santosh M and Nair N G K 1986 Petrogenesis of Angadimogar syenite, Kerala and its taphrogenic affiliation; J. Geol. Soc. India 27 494-507.

Searle M P, Parrish R R, Hodges K V, Hurford A, Ayres M W and Whitehouse M J 1997 Shisha Parigma leucogranite, South Tibetan Himalaya: field relations, geochemistry, age, origin, and emplacement; J. Geol. 105 295-307.

Shand S J 1943 The Eruptive rocks, 2nd edn (New York: John Wiley) 444p.

Streckeisen A L 1976 To each plutonic rock its proper name; Earth Sci. Rev. 12 1-33.

Streckeisen A L and Le Maitre R W 1979 A chemical approximation to the modal QAPF classification of the igneous rocks; Neu. Jahr. Mineral. 136 169-206.

Strong D F and Hammer S K 1981 The leucogranites of southern Brittany: origin by faulting, frictional shearing, fluid flux, and fractional melting; Can. Mineral. 19 $163-176$

Zhao J-X, Shiraishi K, Ellis D J and Sheraton J W 1995 Geochemical and isotopic studies of syenites from the Yamato mountains, East Antarctica: implications for the origin of syenitic magmas; Geochem. Cosmochim. Acta 59 1363-1382. 